Економічні науки: збірник наукових праць Луцького національного технічного університету. - Серія "Регіональна економіка". - Випуск 15 (59). - Редкол.: відп. ред. д.е.н., професор Л.Л. Ковальська. - Луиьк: ІВВ Луиького НТУ, 2018. - 292 с.

УДК 330.341.1:332.1

Куцай Н.С., к.е.н., доцент

Луцький національний технічний університет

\title{
АНАЛІЗ СТАНУ ТЕНДЕНЦІЙ РОЗВИТКУ ІННОВАЦІЙНОÏ ІНФРАСТРУКТУРИ РЕГІОНУ
}

Проведено аналіз стану інноваційної інфраструктури регіону. Виявлено чинники, що стримують розвиток інноваційної інфраструктури регіону. Визначено напрями та завдання для покращення інноваційної інфраструктури регіону.

Ключові слова: регіон, інноваційна інфраструктура, інноваційний розвиток, формування інноваційної інфраструктури регіону.

\section{Kutsai N.}

\section{ANALYSIS OF THE STATE OF TRENDS INNOVATIVE INFRASTRUCTURE OF THE REGION}

World experience shows that for the breakthrough innovative development of the country, the creation of infrastructure support is of particular importance, which allows for the implementation of highly effective types of innovations on a wide scale.

Innovative development of the region must necessarily be based on scientific and technological progress, the development of information technologies, scientific and production potential, all this can be called - an innovative infrastructure, which includes: the sphere of concentration of scientific achievements in production; authorities of different levels; public organizations and business associations; organizations involved in training, the creation of a scientific society, holding scientific events (conferences, round tables, fairs, exhibitions); large-scale innovation centers; innovative clusters based on the scientific community, industrial and technological centers.

Therefore, at this stage of development, both the country and the region, there is a need to analyze the state of development of innovation infrastructure. This will create the necessary basis for making informed decisions about the choice of directions of innovation development and provide the necessary balance of innovative resources of the region.

Innovative infrastructure plays a key role in the development of the region's economy, since its existence is associated with the state of productive forces and the territorial division of labor, as well as the efficiency of the sphere of material production. Innovative infrastructure, on the one hand, depends on the pace of 
Економічні науки: збірник наукових праць Луцького національного технічного університету. - Серія "Регіональна економіка". - Випуск 15 (59). - Редкол.: відп. ред. д.е.н., професор Л.Л. Ковальська. - Луцьк: ІВВ Луцького НТУ, 2018. - 292 с.

modernization, and on the other hand, it is itself the supplier of the region's economic growth.

Innovative infrastructure of every region of Ukraine has its own peculiarities and differences in functioning. This can be seen from the example of the innovative infrastructure of the Volyn region, which has a number of prevailing geographic, historical, economic, resource, socio-cultural and other factors of economic development, but unfortunately, it occupies only the average position in Ukraine on achievements in innovation activity.

The conducted analysis of the objects of innovative infrastructure in the Volyn region made it possible to identify the operating organizations of the region, which are engaged in innovation activities and assess the level of their activities.

According to the results of conducted researches and according to the information of the Main Department of Statistics in Volyn Oblast in 2017, 17 industrial enterprises carried out innovation activities (in 2016 - 11), which is by $5.8 \%$ more than in the previous year.

In order to improve the innovation infrastructure of the region, to intensify inventive, innovative and scientific activity, it is necessary to focus efforts of all participants of this innovation process on the following directions:

1) ensuring the development and prioritization of perspective innovative projects that have a decisive impact on the efficiency and competitiveness of the region's economy; improvement of mechanisms of provision of preferential loans of banks for the implementation of innovative projects;

2) rehabilitation and development of existing production-technological and scientific potential, formation of interregional innovation market; science-intensive and innovative entrepreneurship;

3) legislative regulation of the sphere of intellectual property in order to commercialize it;

4) development of the objects of innovative infrastructure and raising the level of education of their leadership, for example, techno parks as places of joint assembly and free cooperation of investors and producers, students and scientists;

5). Constant updating of the database of new technologies, innovative projects and the search for potential investors;

6) developing a mechanism for providing incentives to enterprises that introduce innovative products and new technologies.

Key words: region, innovation infrastructure, innovative development, formation of innovative infrastructure of the region.

Куцай Н.

\section{АНАЛИЗ СОСТОЯНИЯ ТЕНДЕНЦИЙ РАЗВИТИЯ ИННОВАЦИОННОЙ ИНФРАСТРУКТУРЫ РЕГИОНА}

Проведен анализ инновационной инфраструктуры региона. Выявлены факторы, сдерживающие развитие инновационной инфраструктуры региона. 
Економічні науки: збірник наукових праць Луцького національного технічного університету. - Серія "Регіональна економіка". - Випуск 15 (59). - Редкол.: відп. ред. д.е.н., професор Л.Л. Ковальська. - Луиьк: ІВВ Луиького НТУ, 2018. - 292 с.

Определены направления и задачи для улучшения инновационной инфраструктуры региона.

Ключевые слова: регион, инновационная инфраструктура, инновационное развитие, формирование инновационной инфраструктуры региона.

Постановка проблеми у загальному вигляді і її зв`язок 3 важливими науковими та практичними завданнями. Світовий досвід показує, що для проривного інноваційного розвитку країни особливого значення набуває створення інфраструктурного забезпечення, що дозволяє здійснювати в широких масштабах високоефективні види інновацій.

Інноваційний розвиток регіону обов'язково має базуватися на науково-технічному прогресі, розвитку інформаційних технологій, науково-виробничому потенціалі, все це можна назвати - інноваційною інфраструктурою, яка включає в себе: сферу зосередження наукових досягнень у виробництві; органи влади різного рівня; громадські організації та бізнесоб'єднання; організації, що займаються тренінгами, створенням наукового товариства, проведення наукових заходів (конференцій, круглих столів, ярмарків, виставок); масштабні інноваційні центри; інноваційні кластери на базі наукової спільноти, промислового і технологічних центрів.

Тому, на даному етапі розвитку, як країни, так і регіону виникає необхідність аналізу стану розвитку інноваційної інфраструктури. Це дозволить створити необхідне підгрунтя для прийняття обгрунтованих рішень щодо вибору напрямів інноваційного розвитку та забезпечити необхідний баланс інноваційних ресурсів регіону.

Аналіз останніх досліджень, у яких започатковано вирішення проблеми. Теоретичні розробки, присвячені питанням інноваційного розвитку як стратегічної умови забезпечення конкурентоспроможності країни, а також проблеми інноваційного розвитку регіонів відображені в працях А. Анчишкіна, Н. Бекетова, Дж. Кейнса, Г. Менша, Й. Шумпетера. 
Економічні науки: збірник наукових праць Луцького національного технічного університету. - Серія "Регіональна економіка". - Випуск 15 (59). - Редкол.: відп. ред. д.е.н., професор Л.Л. Ковальська. - Луцьк: ІВВ Луцького НТУ, 2018. - 292 с.

Безпосередньо вивченням різних аспектів формування та функціонування різних аспектів інноваційної інфраструктури займалися Г. Баришева, П. Завлін, М. Козоріз, М. Портер, Н. Рудь, В. Соловйов, Л. Федулова та ін.

Незважаючи на очевидний прогрес, досягнутий в питаннях теоретичних та прикладних досліджень інноваційної інфраструктури в Україні, залишаються питання пов'язані 3 аналізом стану тенденцій розвитку інноваційної інфраструктури в регіонах, зокрема і Волинському.

Цілі статті. Здійснити аналіз стану тенденцій розвитку інноваційної інфраструктури у Волинському регіоні. Виявити чинники, які впливають на розвиток інноваційної інфраструктури регіону.

Виклад основного матеріалу дослідження 3 повним обгрунтуванням отриманих наукових результатів.

Інноваційна інфраструктура займає ключове місце в розвитку економіки регіону, оскільки іiі існування пов'язане зі станом продуктивних сил і територіальним поділом праці, а також ефективністю функціонування сфери матеріального виробництва. Інноваційна інфраструктура, 3 одного боку залежить від темпів модернізації, а 3 іншого - сама виступає постачальником економічного зростання регіону.

Інноваційна інфраструктура кожного регіону України має свої особливості та відмінності у функціонуванні. Це можна прослідкувати на прикладі інноваційної інфраструктури Волинського регіону, який має низку переваг в географічних, історичних, економічних, ресурсних, соціально-культурних та інші факторах економічного розвитку, але, на жаль, займає лише середні позиції по Україні $з$ досягнень в інноваційній діяльності.

Проведений аналіз об єктів інноваційної інфраструктури в Волинському регіоні дав можливість виявити діючі організації регіону, які займаються інноваційною діяльністю та оцінити рівень їх діяльності.

За результатами проведених досліджень та за інформацією Головного управління статистики у Волинській 
Економічні науки: збірник наукових праць Луцького національного технічного університету. - Серія "Регіональна економіка". - Випуск 15 (59). - Редкол.: відп. ред. д.е.н., професор Л.Л. Ковальська. - Луцьк: ІВВ Луиького НТУ, 2018. - 292 с.

області у 2017 році інноваційні заходи здійснювали 17 промислових підприємств (у 2016 р. - 11), що на 5,8 \% більше, ніж попереднього року (табл. 1) [1].

Таблиця 1

Основні показники інноваційної діяльності у Волинській області

\begin{tabular}{|c|c|c|c|c|}
\hline Показники & 2014 & 2015 & 2016 & 2017 \\
\hline $\begin{array}{lr}\text { Кількість } & \text { інноваційно } \\
\text { активних підприємств, од. }\end{array}$ & 30 & 12 & 11 & 17 \\
\hline $\begin{array}{l}\text { Рівень інноваційної } \\
\text { активності підприємств, у } \\
\% \text { до загальної кількості } \\
\text { промислових підприємств }\end{array}$ & 10,8 & 11,5 & 10,2 & 16,0 \\
\hline $\begin{array}{lr}\text { Обсяг } & \text { реалізованої } \\
\text { інноваційної } & \text { продукції, } \\
\text { млн. грн. } & \end{array}$ & 316,6 & 383,6 & 90,7 & 66,8 \\
\hline $\begin{array}{l}\text { Обсяг } \quad \text { реалізованої } \\
\text { iнноваційної продукції, у } \\
\% \text { до загального обсягу } \\
\text { промислової продукції }\end{array}$ & 2,5 & 2,2 & 1,4 & 0,3 \\
\hline $\begin{array}{l}\text { Обсяг реалізованої } \\
\text { інноваційної продукції за } \\
\text { межі України, млн. грн. }\end{array}$ & 89,9 & 168,0 & 71,5 & 4,8 \\
\hline $\begin{array}{l}\text { Обсяг реалізованої } \\
\text { інноваційної продукції за } \\
\text { межі України, у \% до } \\
\text { загального обсягу } \\
\text { реалізованої інноваційної } \\
\text { продукції }\end{array}$ & 28,4 & 43,8 & 28,0 & 7,2 \\
\hline $\begin{array}{lr}\text { Обсяг } & \text { інноваційних } \\
\text { витрат у } & \text { промисловості, } \\
\text { млн. грн. } & \\
\end{array}$ & 192,5 & 65,2 & 147,4 & 162,0 \\
\hline
\end{tabular}

У 2015 році питома вага підприємств, що займалися інноваціями дещо збільшилася до 11,5\% проти 10,8 \% у 2014 році, далі у 2017 році спостерігається невелике зростання частки - до 16,0\%.

Обсяг реалізованої інноваційної продукції за 2017 рік становив 66,8 млн. грн., що становить 0,3 \% від загального обсягу реалізованої промислової продукції (2014 р. - 2,5 \%; 
Економічні науки: збірник наукових праць Луцького національного технічного університету. - Серія "Регіональна економіка". - Випуск 15 (59). - Редкол.: відп. ред. д.е.н., професор Л.Л. Ковальська. - Луцьк: ІВВ Луцького НТУ, 2018. - 292 с.

2016 р. - 1,4 \%). Загалом, з 2015 року спостерігається тенденція до зниження питомої ваги реалізованої інноваційної продукції.

Протягом 2014-2017 років спостерігалось значне зниження загальної суми витрат на інноваційну діяльність: 3 192,5 млн. грн. у 2014 році до 162, 0 млн. грн. у 2017 році.

Більше половини інноваційно-активних підприємств регіону задіяні у виробництві харчових продуктів, виготовленні виробів 3 деревини, виробництві паперу та поліграфічній діяльності, машинобудуванні.

Впровадження технологічних інновацій дало змогу підприємствам оновити продукцію, підвищити іiі технічний рівень та конкурентоспроможність. Серед підприємств, які найбільш активно впроваджували інновації: товариства 3 обмеженою відповідальністю «Модерн-Експо», публічні акціонерні товариства «СКФ Україна», «Теремно-Хліб», «ВГП», ДП «Автоскладальний завод №1» АТ «АК «Богдан Моторс» та ПрАТ «Теріхем-Луцьк».

В регіоні сформована база анкет інноваційних проектів та пропозицій. Зазначені анкети розміщенні на офіційному сайті облдержадміністрації. Крім того, перелік вищезазначених анкет включений до презентаційного CD-диску «Волинь запрошує до співпраці», який розроблений українською, російською, польською та англійською мовами [2].

Основними чинниками, що стримують розвиток інноваційної інфраструктури регіону є:

- недостатній рівень кооперації між підприємствами i науковими організаціями;

- високий ступінь зносу основних фондів на підприємствах;

- низька платоспроможність споживачів, що мають потребу у високотехнологічній продукції;

- домінування галузей 3 низьким рівнем обробки сировини;

- недостатній рівень комерціалізації науково-технічних розробок та передачі їх до сфери виробництва. 
Економічні науки: збірник наукових праць Луцького національного технічного університету. - Серія "Регіональна економіка". - Випуск 15 (59). - Редкол.: відп. ред. д.е.н., професор Л.Л. Ковальська. - Луцьк: ІВВ Луцького НТУ, 2018. - 292 с.

Для покращення інноваційної інфраструктури регіону, активізації винахідницької, раціоналізаторської та наукової діяльності необхідно зосередити зусилля усіх учасників цього інноваційного процесу на наступних напрямках:

1) забезпечення розроблення та пріоритетного розвитку перспективних інноваційних проектів, які мають вирішальний вплив на ефективність та конкурентоспроможність економіки регіону; удосконалення механізмів надання пільгових кредитів банків на впровадження інноваційних проектів;

2) відновлення та розвиток наявного виробничотехнологічного i наукового потенціалу, формування міжрегіонального інноваційного ринку; наукоємного та інноваційного підприємництва;

3) законодавче врегулювання сфери інтелектуальної власності з метою їі комерціалізації;

4) розвиток об'єктів інноваційної інфраструктури та підвищення освіченості їх керівництва, наприклад, технопарків як місця спільного зібрання та вільної співпраці інвесторів і виробників, студентів та науковців;

5) постійне оновлення бази даних нових технологій, інноваційних проектів та пошук потенційних інвесторів;

6) розроблення механізму щодо надання пільг підприємствам, які впроваджують інноваційну продукцію та новітні технології.

При цьому стратегічно важливим кроком $є$ залучення провідних регіональних вищих навчальних закладів освіти до надання послуг інформаційно-довідкового, освітнього та експертно-консалтингового характеру.

Висновки. Отже, серйозним завданням на найближчу перспективу $\epsilon$ : формування та розвиток такої інноваційної інфраструктури, яка дозволить забезпечити необхідний баланс ресурсів інноваційних підприємств регіону; координація дій обласної державної адміністрації, обласної ради, районних державних адміністрацій, наукових установ та організацій на підтримання сприятливих умов розвитку інноваційної інфраструктури Волинського регіону за допомогою створення 
Економічні науки: збірник наукових праць Луцького національного технічного університету. - Серія "Регіональна економіка". - Випуск 15 (59). - Редкол.: відп. ред. д.е.н., професор Л.Л. Ковальська. - Луцьк: ІВВ Луцького НТУ, 2018. - 292 с.

нових технологій, засобів виробництва, наукоємної та конкурентоспроможної продукції, що є передумовою успішного проведення реформ в регіоні; реалізація кластерного підходу до розвитку інноваційного бізнесу, який буде сприяти зростанню якісних параметрів виробництва, розвитку малого та середнього підприємництва та збільшення зайнятості населення регіону.

1. Державна служба статистики України: офіц. веб-сайт // [Електронний ресурс]. - Режим доступу: http://www.ukrstat.gov.ua/.

2. Офіційний сайт Волинської обласної ради // [Електронний ресурс]. Режим доступу: http://volynrada.gov.ua/. 